\title{
AN ANALYSIS OF VERBAL AND NON-VERBAL COMMUNICATION IN AUTISTIC CHILDREN
}

\author{
Weny Anita Febriantini ${ }^{1}$, Rahima Fitriati ${ }^{2}$, Lulud Oktaviani ${ }^{3}$ \\ Universitas Negeri Malang ${ }^{\mathbf{1}}$ \\ Universitas Muhammadiyah Malang \\ Universitas Teknokrat Indonesia ${ }^{3}$ \\ wenyanita11@gmail.com ${ }^{1}$ \\ fitriatirahima@gmail.com ${ }^{2}$ \\ lulud_oktaviani@teknokrat.ac.id ${ }^{3}$
}

\begin{abstract}
Autism is a developmental disorder characterized by difficulties with social interaction and communication, and by restricted and repetitive behavior. Autistic is a person affected by autism. The level of autism of each individual is varied. It can range from mild to severe. Due to this condition, the person shares some symptoms of difficulties with social interaction. To make them involved in social interaction, it needs special effort to make them be able to speak or communicate first. For this reason, there should be the use of a combination of verbal and non-verbal communication. Thus, this study attempted to investigate the process of using both kinds of communication in teaching children with autism since children are easier to be treated than adults. To make the distinct result, the participants were from a different level of autism. Then, based on the observation and interview, the findings showed that the verbal and non-verbal communication used by the therapist in teaching autistic children can enhance their social interaction and communication skills.
\end{abstract}

Keywords: autistic, verbal communication, non-verbal communication, children, speaking.

\section{To cite this article:}

Febriantini, W. A., Fitriati, R., \& Oktaviani, L. (2021). An Analysis of Verbal and Non-Verbal Communication in Autistic Children. Journal of Research on Language Education, 2(1), 53-56.

\section{INTRODUCTION}

Every child is unique and has different skills and difficulties. It also happens for children who have some sort of disorder, such as autism. According to Ousley and Cermak (2013), "Autism spectrum disorder (ASD) is a behaviorally defined neurodevelopmental disorder associated with the presence of social-communication deficits and restricted and repetitive behaviors". Autistic children cannot be generalized into one group because they all differ from each other in terms of different symptoms that may lead to different types and levels of autism. Moreover, Rapin and Tuchman (2008) said that autism cannot be defined as a disease; rather it is a symptom of a typical development of the immature brain. Autism is a behaviorally distinct syndrome with many known and unknown causes. It has a wide range of severity and it has no clear borders, so symptoms of the disorder cannot be fenced. It can be like disorders of sleep and feeding, gastrointestinal tract symptoms, obesity, seizures, attentiondeficit/hyperactivity disorder, anxiety, and wandering (Hyman, Levy, and Myers, 2020).

Autistic children encounter difficulties regarding communication that children without a disorder do not have to encounter. They cover a wide range of cognitive handicaps, including the progress of their speech development and the understanding of language (Rutter, 1974 in Bartak, Rutter \& Cox, 1975). Besides, Rapin \& Tuchman (2008) argued that with the slow development of speech, autistic children also have problems with social interaction which results in them secluding themselves and not communicating with others in a way that seems regular to other people. As stated by Sari (2018), interaction has emerged from verbal communication and nonverbal communication that promote successful interactive systems in the teaching and learning process. Thus, diagnosing as early as possible prevents them from another problems in their future (Hosozawa, Sacker, and Cable, 2021), and teaching and learning verbal skills have to be done in an adapted way so that children with autism still acquire a large vocabulary and certain language skills.

An alternative procedure that may evolve speech development in autistic children is simultaneous communication, like how parents and children interact and speak during playing (Lewis, 2003). It can be the use of spoken language and signing of keywords. According to Paul (2008), the intervention in pre-linguistics stage 
and adult direction method improve language and communication development. Many autistic children in such treatment programs have demonstrated increases in spoken language development (Yoder \& Layton, 1988). The result of the study showed that the combination of sign and speech helped autistic children to increase their oral language skills after participating in the training. This could indicate that combining non-verbal communication with spoken words increases the level of language ability of autistic children.

Many studies have discovered a common denominator named non-verbal communication, a sign language that can be facial expression, or body movement (Buck and VanLear, 2002). Non-verbal communication seems to be a tool that can help improve the language skills of children with autism. Bartak, Rutter, and Cox (1975) found that children with autism score higher on tests that include non-verbal elements, than children without a disorder. When non-verbal elements, such as gaze, pointing, and mimicking were involved in the experiment, autistic children would recognize the displayed item faster. It is also Wing \& Gould (cited by Ricks \& Wing, 1975) supported by showed that implementing non-verbal cues while talking to children with autism is helpful in terms of their understanding of what is verbally said. Longitudinal studies by Drew et al. (2002) also showed that incorporating non-verbal communication into language learning helps autistic children acquire more new words over some time. Niederer (2013) also stated that there is a huge impact in implementing non-verbal communication in improving language acquisition of autistic children.

Lord et al. (2000) showed that children with mental retardation, with or without autism, appear more socially competent, less anxious, and more flexible when the language demands are low concerning their level of language ability. This shows that language is a problem for autistic children, but that language and autism diagnoses are not always connected. Although verbal communication is problematic for most of them, non-verbal communication could help these children to connect to the outer world. Autistic children have been found to show a limited range of non-verbal behaviors. In particular, less frequent use of eye contact, pointing, and showing objects has been reported (Stone, et al., 1997). In their study, autistic children have also been reported to be more likely to use pointing to request than for indicating interest. Early non-verbal communication and functional play skills have been linked to gains in language skills. One to three-year-old children with autism who responded more frequently to calls for joint attention by others made larger gains in language skills throughout both 1 year (Mundy et al., 1990 in Siller \& Sigman, 2002) and 9 years (Sigman \& Ruskin, 1999 in Siller \& Sigman, 2002) than children with autism who initially responded less to others' calls for joint attention, this supports the idea that non-verbal communication will help autistic children learn a language or new words.

As mentioned above, this study tries to investigate the use of verbal and non-verbal communication in developing communication skills of autistic children. Based on the studies above, it is proven that verbal and nonverbal communication are interrelated to each other in developing autistic children's communication skills. However, there was no deeper explanation about the process of verbal and non-verbal communication applied in developing communication skills of children with different levels of autism. Thus, this study aims to discover the process of verbal and non-verbal communication applied in developing the two levels of autistic children's communication skills.

\section{RESEARCH METHOD}

The objective of this study was to investigate the process of developing communication skills in autistic children by combining verbal and non-verbal communication. Thus, the descriptive qualitative research method is used to obtain the data.

This study involved 2 autistic children who were 10 and 12 years old. These children were in the therapy center to get special treatment dealing with their autism. Both children had a different level of autism and also had a different length of time in joining the therapy center. these two children were selected because among all the autistic children in that therapy center, only the two selected children had better interaction and communication. Another reason was that they had a quite different level of autism that might give a distinct comparison and lead to the varied findings.

The writer used two kinds of techniques to obtain the data; observation, and interview. The observation was done to investigate directly the process of using verbal and non-verbal communication in developing communication skills. After doing the observation, interview was conducted to get deeper information.

To analyze the data from observation, the data were categorized into two types, verbal and non-verbal communication. Moreover, the data from the interview was to add the information for the whole collected data. Then, it is used to correlate how verbal and non-verbal communication can enhance the communication skills in autistic children.

\section{FINDINGS AND DISCUSSION}

Based on the result of data analysis from observation, it was found that both participants had a different level of autism. The participant who was 10 years old (A) had a better way of communication than the other one 
who was 12 years old (B). Participant A got quite clear pronunciation in speaking, yet he got a little bit difficult in pronouncing $\mathrm{R}$. On the other hand, participant $\mathrm{B}$ could be able to pronounce only some vocals yet he lost many consonants. This condition made it him difficult in expressing what he wanted to say and also might lead to misunderstanding in communication. This way, the role of the therapist is crucially needed. The therapist has to know what the best way in making both of them improve their communication skill based on their different ability.

\section{The process of verbal communication}

The data were obtained from the therapist's instruction in the process of teaching autistic children. The process of teaching autistic children that involved verbal communication could be shown in the step of asking the children to imitate what the therapist said. In this session, the therapist showed several flashcards and said a different word that represents the picture in the flashcard. The pictures are about vegetables, colors, activities, bedroom set, and bathroom accessories. The therapist had different times in giving therapy to both participants. So, the therapist could focus on only one participant while another participant was given another activity. In engaging verbal communication, the therapist stimulated the participants to repeat what she said after showing the flashcards. The participants were expected to speak clearly in pronouncing every word.

\begin{tabular}{|c|c|}
\hline Participant A & $\begin{array}{l}\text { - Be able to imitate the words almost clearly yet it will get unclear when it } \\
\text { comes to the word with R } \\
\text { Example: } \\
\quad \text { Clear words } \rightarrow \text { kuning, hijau, membaca } \\
\quad \text { Uncllear words } \rightarrow \text { merah, tempat tidur } \\
\text { - Be able to memorize the words, so he can recognize the flashcards given } \\
\text { to him previously. } \\
\text { - Be able to answer the short questions given by the therapist: name, father's } \\
\text { and mother's name, and the therapist's name well }\end{array}$ \\
\hline Participant B & $\begin{array}{l}\text { - Be able to imitate the words with unclear pronunciation. } \\
\text { - Example: kuning (ui), hijau (ijau), merah (meah), ibu (iu) } \\
\text { - Be able to answer the short questions given by the therapist: name, father's } \\
\text { and mother's name, and the therapist's name yet with the unclear } \\
\text { pronunciation. }\end{array}$ \\
\hline
\end{tabular}

\section{The process of non-verbal communication}

In the process of imitating, the therapist said that the participants subconsciously did the non-verbal communication. The therapist also said that after imitating the words, the participants were asked to guest the flashcards given previously. Then, the therapist checked the participants' memorization by asking them to point out the provided flashcards. An example of this session was when the therapist provided several flashcards on the table. She said "kasih bu Ida wortel". The participants would select and directly took the picture of carrot and gave the card to the therapist. When they took the wrong card, the therapist did not want to receive the card which means it would allow them to select the right card. Besides, the participants liked to point out their bottles when they felt thirsty. The therapist's reaction was just giving her a gesture to say "no" to show them that they should focus on learning first.

\section{CONCLUSION}

Based on the theories and the previous research that showed the effective correlation between verbal and non-verbal communication in improving the communication skill in autistic children, this study has proven this kind of motion. Therefore, as the researchers can conclude to make autistic children get better development in communication skills, it should be taught the combination between verbal and non-verbal communication constantly or make it routine to achieve the best improvement.

\section{REFERENCES}

Bartak, L., Rutter, M., \& Cox, A. (1975) A Comparative Study of Infantile Autism and Specific Developmental Receptive Language Disorder: I. The Children. The British Journal of Psychiatry, 126, 127 - 145.

Buck, R., \& VanLear, C. A. (2002). Verbal and Nonverbal Communication: Distinguishing Symbolic, Spontaneous, and Pseudo-Spontaneous Nonverbal Behavior. Journal of Communication, 52(3), 522 - 541. DOI: 10.1111/j.14602466.2002.tb02560.x

Drew, A., Baird, G., Baron-Cohen, S., Cox, A., Slonims, V., Wheelwright, S., Swettenham, J., Berry, B., \& Charman, T. A pilot randomised control trial of a parent training intervention for pre-school children with autism (Preliminary Findings and Methodological Challenges). European Child \& Adolescent Psychiatry, 11(6), 266-272. DOI: 10.1007/s00787002-0299-6.

Hosozawa, M., Sacker, A., \& Cable, N. (2021). Timing of diagnosis, depression and self-harm in adolescents with autism spectrum disorder. Autism, 25(1), 70-78. DOI: 10.1177/1362361320945540. 
Hyman S. L., Levy, S. E., \& Myers S. M. (2020). Identification, Evaluation, and Management of Children With Autism Spectrum Disorder. Pediatrics, 145(1).

Lewis, V. (2003). Play and language in children with autism. Autism, 7(4). DOI: 10.1177/1362361303007004005.

Lord C., Risi S., Lambrecht, L., Cook, E. H. Jr, Leventhal, B. L., DiLavore, P.C., Pickles, A., Rutter, M. (2000). The autism diagnostic observation schedule-generic: a standard measure of social and communication deficits associated with the spectrum of autism. J Autism Dev Disord, 30(3):205-23.

Niederer, S. (2013). Regulation of ion gradients across myocardial ischemic border zones: a biophysical modelling analysis. PLoS ONE, 8(4): e60323. DOI: https://doi.org/10.1371/journal.pone.0060323

Ousley, O. \& Cermak, T. (2013). Autism Spectrum Disorder: Defining Dimensions and Subgroups. Current Developmental Disorders Reports, 1(1), 20-28. DOI: 10.1007/s40474-013-0003-1

Paul, R. (2008). Interventions to Improve Communication. Child Adolesc Psychiatr Clin N Am, 17(4): 835-x. DOI: $10.1016 /$ j.chc.2008.06.011

Rapin, I. \& Tuchman, R. F. (2008). Autism: Definition, Neurobiology, Screening, Diagnosis. Pediatric Clinics of North America, 55(5), $1129-1146$.

Ricks, D. M. \& Wing, L. (1975). Language, communication, and the use of symbols in normal and autistic children. Journal Autism Child Schizophr, 5(3):191-221. DOI: 10.1007/BF01538152.

Sari, F. M. (2018). Patterns of Tseaching-Learning Interaction in the EFL Classroom. Teknosastik: Jurnal Bahasa dan Sastra, 16(2), 41-48.

Siller, M. \& Sigman, M. (2002) The Behaviors of Parents of Children with Autism Predict the Subsequent Development of Their Children's Communication. Journal of Autism and Developmental Disorders, 32(2), 77 - 89.

Stone, W. L., Ousley, O. Y., Yoder, P. J., Hogan, K. L. \& Hepburn, S. L. (1997) Nonverbal Communication in Two and ThreeYear-Old Children with Autism. Journal of Autism and Developmental Disorders, 27(6), 677 - 696.

Yoder, P. J. \& Layton, T. L. (1988) Speech Following Sign Language Training in Autistic Children with Minimal Verbal Language. Journal of Autism and Developmental Disorders, 18(2), 217 - 229.

\section{BIOGRAPHIES OF AUTHORS}

Weny Anita Febriantini was graduated from Universitas Negeri Malang. She had been teaching English for Specific Purposes (ESP) for the last 5 years in Universitas Muhammadiyah Malang. Along with her profession as an ESP lecturer, she had published two books namely English for Biology, 2016; and English for Math, 2017. She also has conducted several research regarding English Language Teaching.

Rahima Fitriati was graduated from Universitas Negeri Malang. She has been teaching English for Specific Purposes since 2014 in Universitas Muhammadiyah Malang. Along with her profession as an ESP lecturer, she had published two books namely English for Mechanical Engineering, and English for Law. Both books are published in 2017. She also has written several research regarding English Language Teaching.

Lulud Oktaviani was graduated from Universitas Negeri Malang. She is an English Education Lecturer in Universitas Teknokrat Indonesia (UTI). Besides teaching, she is also active in joining as a presenter at national and international conferences and publishing her research in proceedings and journals. Her research interest is teaching media, English teaching, and learning, English as a second language. Moreover, she also has obtained funding from the Directorate of Research and Community Service in Higher Education five times for Penelitian Dosen Pemula (PDP) and Program Kemitraan Masyarakat (PKM). 